\title{
INVESTMENT POLICY OF UKRAINE IN THE AGRICULTURAL SECTOR
}

\author{
Iryna BEZPYATA', \\ Mykolaiv National Agrarian University, Ukraine
}

\begin{abstract}
The aim of this article is a study of features of investment politics of the state in the agrarian sector of economy, determination of basic problems of bringing in of investments and grant of suggestions how to form the investment politics in the agrarian sector of economy in Ukraine. One of the issues in agrarian sector of economy development in Ukraine is providing of agriculture necessary financial and material resources the basic source of that are investments. Presently Ukraine is in an investment crisis that is characterized by the decline of investment activity of management subjects because of the low level of investor's activity. Reason of that is an unfavourable investment climate in a country that was appeared because of unstable position of country and risky economic position. Agriculture is a food industry of national economy her state depends on the facilities inlaid in her development, namely - from intensity of investment activity. Exactly active government investment activity in an agrarian sector is the mortgage of his stable development and effectiveness. Research methodology consists, that the reason of agricultural production crisis, foremost, because of government control and agroindustrial complex support weakened role. In the developed countries, vice versa, the value of state support of agroindustrial complex increases. Charges on agrarian politics realization as a line and indirect support grow constantly, as it demonstrates the hands-on experience in EU. The general chart of government control of investing terms levers in the agrarian sector of economy is certain by us. The results of research is showing that an important condition necessary for private capital investments (both foreign and domestic) is a permanent and well-known set of the norms and rules, set in the way that potential investors could understand and foresee that these rules will be used to their activity. Practical value is certain by success of investment projects that depend on the openness of government and local self-government bodies, from a dialogue with public and productive sphere (agribusiness). A value/originality. Research results allow defining basic obstacles in bringing in of investments in the agrarian sector of economy in Ukraine. Showing up: the high risks, related to the specific of agriculture (climatic terms, duration of productive process), ecological aspect and economic situation in a country on the whole; subzero investment attractiveness of industry and agrarian enterprises, undeveloped infrastructure; high level of lending rates of commercial banks; unwithstand politics of state interference and adjusting, does not add the confidence for potential investors.
\end{abstract}

Key words: investments, investing, investment policy, state regulation, agricultural sector.

JEL Classification: Q14, E22, F21

\section{Introduction}

One of issues of agrarian sector economy development in Ukraine in modern terms is providing of agriculture by necessary financial and material resources the basic source of that are investments. Nowadays, Ukraine is in an investment crisis that is characterized by the decline of menage subject's investment activity because of investors activity low level. By reason of that is unfavourable investment climate in a country that in turn arose up through unstable and too risky economic position of country.

In agrarian sector economy of Ukraine in the conditions of investment resources deficit and limit possibilities of state support of investing and presence of high risks level for realization of investment activity, investment politics of the state must be sent to introduction of effective mechanisms of bringing in of home and foreign capital stimulation and creation of effective control system by investment processes in the agrarian sector of economy.

Many scientists-economists devoted the researches to the studies of investing in agriculture questions, among them mark labours of such scientists as: M.V. Bryk, H.YePavlova, A.A. Peresada, P.I. Hajduts'kyj, H.B. Ivanyts'ka, V.I. Kasianiuk, M.I. Kysil', M.Yu. Kodens'ka, H.M. Pidlisets'kyj, M.P. Soroka et al. But realities of present time need permanent corections and input of new

\footnotetext{
Corresponding author:

${ }^{1}$ Department of Economy Enterprises, Mykolaiv National Agrarian University.

E-mail: bezpyata@gmail.com
} 
methods in relation to the features of public investment policy in the agrarian sector of economy.

The aim of this article is a study of investment politics features in the agrarian sector of economy, determination of basic problems of investments bringing in and grant of suggestions in relation to form investment politics in the agrarian sector of economy in Ukraine.

Methodological basis and informative base of publication are materials of magazines, labour of scientistseconomists, Internet- resources, normatively-legal acts. During the research realization were used the systems analysis, synthesis and generalization methods.

\section{Economic crisis effects on consumer behaviour}

One of issues of agrarian sector economy development in modern Ukraine is providing of agriculture by necessary financial and material resources the basic source of that are investments. In nowadays, Ukraine is in an investment crisis that is characterized by the decline of menage subject's investment activity because of investors activity low level. By reason of that is unfavourable investment climate in a country, that in turn arose up through unstable and too risky economic position of country.

In agrarian sector economy of Ukraine in the conditions of investment resources deficit and limit possibilities of state support of investing and presence of high risks level for realization of investment activity, investment politics of the state must be sent to introduction of effective mechanisms of bringing in of home and foreign capital stimulation and creation of effective control system by investment processes in the agrarian sector of economy.

Agriculture is that food industry of national economy, the state of that in direct ratio depends on the money inlaid in her development, namely - from intensity of investment activity. Exactly active government investment activity in an agrarian sector is the mortgage of him stable development and effectiveness.

In scientific literature considerable attention is spared to different approaches of investment politics forming. However almost everybody agree, that complete abandonment from the state investment providing of agricultural commodity producer is not possible through his branch features. At the same time there are different points of view on the level of agrarian sector investment support from the state, when the question is about his basic constituents, their dependence and priority of development on every stage.

A main function of the state in a market economy is not realization of capital investments in a production (except the industries related to national safety or with the consequences of crisis), but conditioning for bringing in of investments, role implementation as guarantor of investments and profits receipt stability. The state must regulate an investment process on legal framework. A public policy must become one of decision factors of the economic adjusting of investment activity in agrarian sector.

For the macroeconomic assistance of investment activity the system of government, at disposal of that there are levers of direct action as the centralized state capital

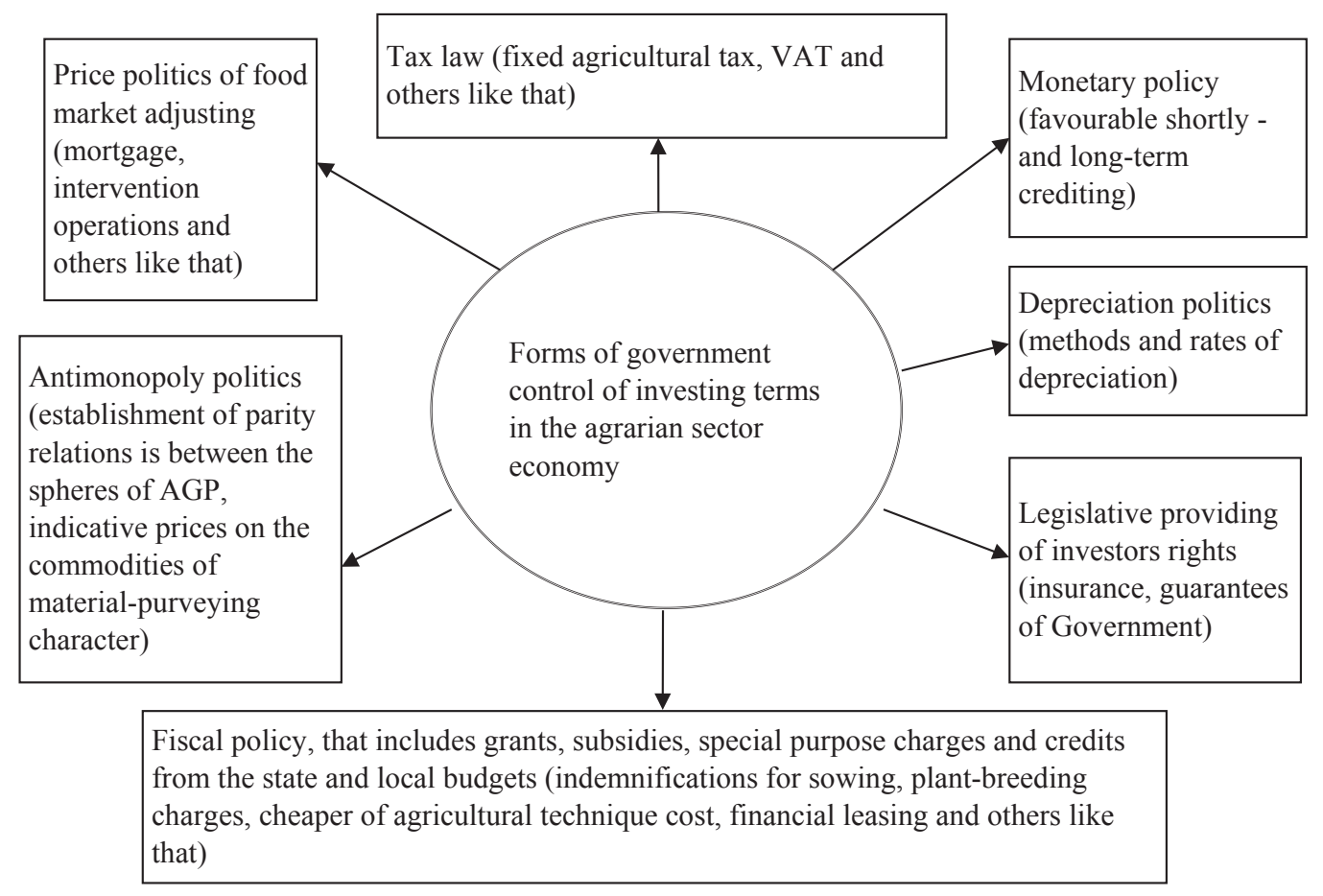

Pic. 1. Levers of government control of investing terms in agrarian sector economy 
investments in the objects of national value, development of public sector of economy, authorities is responsible, so indirect facilities of adjusting of investment environment due to a monetary, budgetary (financing of the separate national programs of strategic character, grant, subsidy and others like that), antimonopoly and depreciation policy (Lanchenko, 2005).

As principal reason of agricultural production crisis many economists name, foremost, weakening of government control and support of agroindustrial complex role. In developed countries, opposite, the value of state support of agroindustrial complex increases. Charges on realization of agrarian politics as a line and indirect support grow constantly, as it asserts the practical worker of EU countries.

The general chart of government investing terms control levers in the agrarian sector of economy is presented on picture 1 .

The monetary state policy influences on investment terms, regulating turnover and work of the banking system, that, essentially, carries out the increase of money in the economic system not always on equivalent basis in relation to agricultural industry. To the basic instruments of monetary accommodation it follows to take:

- the norms of insurance backlogs, that have to belong to commercial banks and to distract certain part of the facilities from the active use for crediting and investing;

- registration rate of the National bank, where it sells credit resources to the commercial banks, increasing or diminishing the volumes of credit sources for financing of investments;

- operations with state securities at the open market. Setting advantageous terms (as a price or dividends) for securities, the state stimulates their purchase legal and natural persons and diminishes the amount of free money that can be used for financing of investments through the banking system (Kasych, 2008).

It should be noted that the features of current unstable (crisis) economic situation limit the scales of commercial banks participation in investment activity. On this process the row of factors influences: contradiction between the rates of percent and risks of loans grant, absence of sufficient backlogs under growing credit risks. In world practice long-term credits, as most reliable, the more subzero have rates of percent, and in Ukraine they behave to the most risk. Banks have a high-profitable alternative of investments in state short-term bonds, and also possibility of the use of them in other profitable short-term operations. The market of corporate Ukraine securities is not enough developed, and equity investment and bond of joint-stock companies in particular agricultural, on the present stage of development of economy are considered banks non-liquid.

Thus, in relation to the mechanism of increase of the long-term part crediting it is expedient to accept the row of measures: to decrease income taxes from long-term credits that is directed in an agrarian sector; to set that banks in that part of these investment credits exceeds a certain limit, get additional tax deductions and others like that. In other words it is necessary not to declare economic reforms in a bank sphere, agrarian sphere, but provide their realization (Nepochatenko, 2008).

\section{Stimulation of the bank's investment activity}

For stimulation of banks investment activity is expedient to apply the leasing charts of crediting that in turn solve problem largely aging materially of technical base and mortgage of enterprises property, that especially topically in an agrarian sector.

Taking into account experience of different countries in relation to organization of agricultural commodity producers crediting, we consider that credit politics for the enterprises of this sphere must include:

- the favourable crediting of agricultural producers, that envisages the increase of long-term credits part, decline of interest rates, development of mortgage operations, as one of forms of the state favourable crediting;

- development of agrarian credit after such directions, as: crediting of producers directly from state sources through the mechanism of mortgage operations;

- development of the mortgage crediting in the commercial system of banks: creation of peasant co-operative credit establishments, integrated structures.

One of directions to activate the investment activity in developed countries agriculture there is a stimulant mechanism of taxation, that includes income taxes (net profit) corporations; real estate, in particular earth; capital that is invested, or capital additions; valueadded; social security of labour employed and excises. Not having regard to such wide list, totally these taxes make from 2,5 to $6 \% \%$ all farmer charges from that an about half is on two taxes: from an income and on the real estate. Much in why explained to the grants of tax deductions, due to that the fiscal functions of taxes are erected to the minimum. Realizations of reforms of the tax system, that envisage privileges in the developed countries, assist active tax stimulation of development of scientific and technical progress that requires additional capital investments.

Budgetary levers are the system of different taxes types, privileges, that create such redistribution system of enterprises and citizens profits in a country that the state considers optimal for forming of sinkhead budget and maintenance at enterprises and businessmen of market stimuli to work and receipt of incomes practically, set by the state. Charges and charges of budget, and also budgetary credits are the ponderable means of the combined demand forming, and through him is stimulation of investments in general and the inter-branch structure. Even the system of the social budgetary programs (not to mention about direct budgetary investments in a public sector) influences on the pattern of demand, because social payments from a budget are got by people that must expend them in the 
market of consumer goods, and it in turn stimulates a production, trade and corresponding investments for this purpose (Plekhanov, 2010).

A large value is acquired by realization of antimonopoly politics, what expedient not only in industries that are natural monopolies, and also in relation to branch and local monopolists, that supply with products for agricultural enterprises and those that buy for them.

To our opinion, in the conditions of Ukraine antimonopoly politics must prevent further monopolization in contiguous with an agrarian production industries. In this situation expedient tactical measures are on the real limitation of profitability of enterprisesmonopolists (in particular, raw material and purveying character) through establishment by them just maximal vacations and minimum purchase prices. Here, certainly, it follows to work out the criteria of intermediary taking and processing enterprises to the category of monopolists, and also to expect a reasonable betweenness by purchase and vacation prices in every special case (Plekhanov, 2010).

Important role in the system of investment processes government control in agriculture must play the mechanism of the minimum assured prices establishment, state mortgage and intervention operations at the food market.

Asknown, practice shows imperfection to the mechanism of pricing in an agrarian sector. A price, as an important element of economic mechanism, performs the duty of financial regulator and must provide the equivalence of exchange between agrarian and by other sectors of economy. It is therefore necessary to support prices at the level of lower limit middle market prices vibrations with the aim of market defence from the envisaged conjuncture price vibrations.

Thus, in basis of investment politics of the state in the agrarian sector of economy must be fixed principles of the actively-passive government control shown mainly in state sponsorship of agriculture enterprises and engineer for an agrarian sector, price, antimonopoly, depreciation politics, development of agrarian market infrastructure, becoming of mortgage relations and others like that.

Thus, the fixed principles of the actively-passive government control must be put in the basis of investment policy of the state in the agrarian sector of economy. The control is shown mainly in state sponsorship of enterprises of agriculture and engineer for an agrarian sector, price,

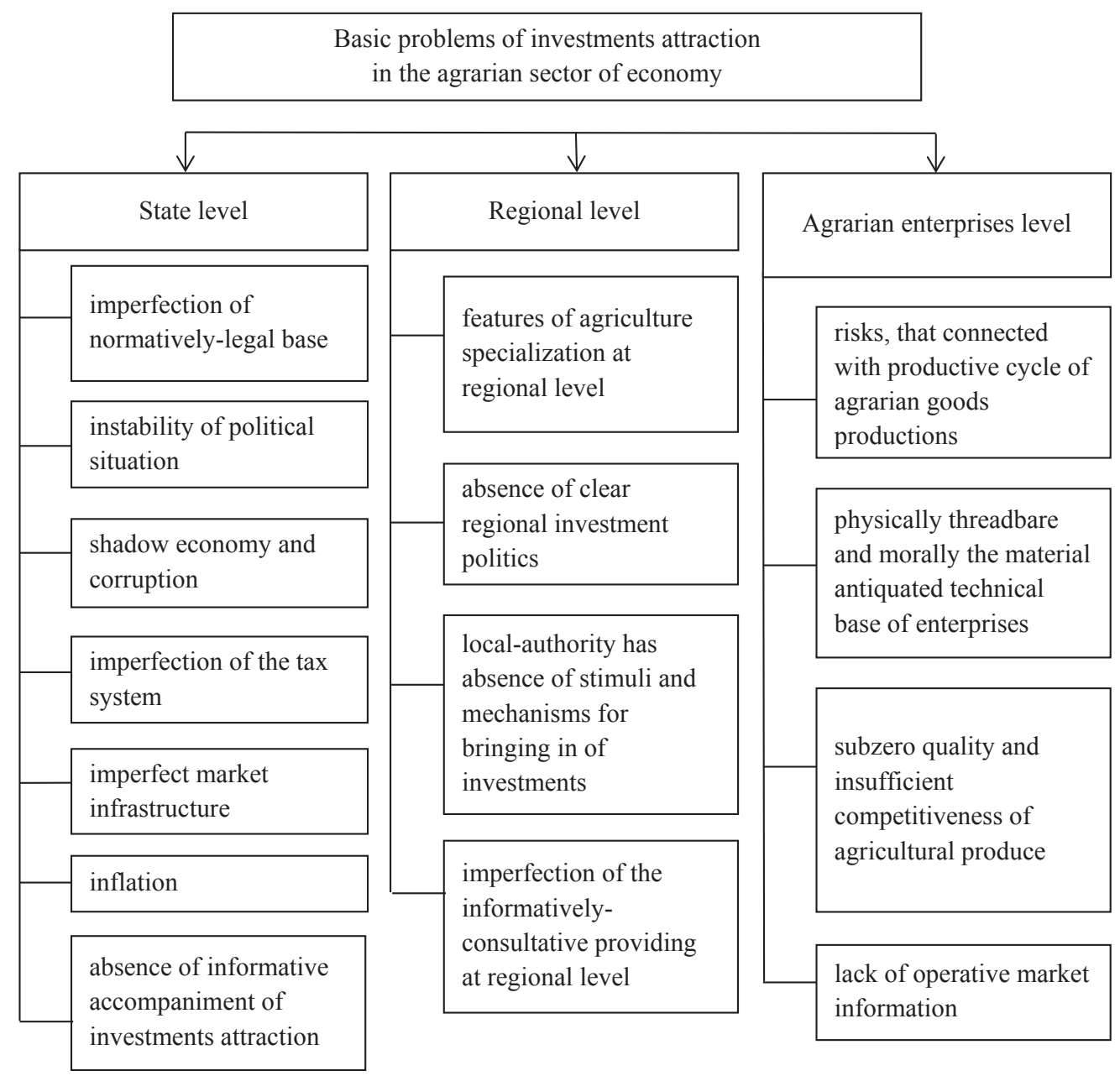

Pic. 2. Basic problems of investments attraction in the agrarian sector of economy 
antimonopoly, depreciation policies, development of agrarian market infrastructure, becoming of mortgage relations, etc.

\section{The basic problems of investments attraction in the agrarian sector}

However, there is a tendency of reduction of volumes of financial resources in an agroindustrial production now.

But, on this time there is a tendency of financial resources volumes reduction in an agroindustrial production. Most agricultural enterprises appeared before the problem of own stock accumulation for realization or modernisation of production. Resource potential is hereupon formed before with every year closes. The actual terms of exploitation of the most fixed assets in times exceed normative. The processes of recreation and updating of material and technical base almost ceased in a village. Now in agriculture, a generous amount mainly functions investment small attractive, out-of-date production capacities unable to produce high-quality foods in accordance with the requirements of international standards. Therefore problem of the investment providing of agrarian production as never acquires actuality, especially on this stage of the state economy development.

The basic problems of investments attraction in the agrarian sector of economy can be distinguished on state, regional levels and at the level of separate agrarian enterprises (picture 2).

To the basic problems at state level it is possible to take:

- imperfection of normatively-legal base;

- instability of political situation;

- shadow economy and corruption;

- imperfection of the tax system;

- an imperfect market infrastructure;

- inflation;

- absence of informative accompaniment of bringing in of investments.

In nowadays, investors that dare to invest in agrarian sector require legislative guarantees, large corporations and investment companies require governmental guarantees and privileges. However the mechanism of legal guarantees realization hasn't exhausted enough yet. Sufficient judicial facilities are besides absent for providing of legal rights observance for investors and spores settlement.

An important condition necessary for private capital investments (both foreign and domestic) is a permanent and well-known set of norms and rules set forth thus, that potential investors could understand and provide, that these rules will be used to their activity. In Ukraine that is in the state of continuous reformation of power, legal mode inconstant.

Laws and rules that often conflict with each other operate on the different levels of power. The additional source of instability is a grant to the laws and instructions of reverse force. Such practice disturbs foreign investors in earnest, especially when legislation touches already existent capital investments.
Also a substantial obstacle on a way for attraction and effective using of investments in an agrarian sector is an imperfect infrastructure. The insufficient amount of corresponding experts, public accountants, consultants restrains the increase of receivables of foreign capital in the agrarian sector of economy. For correction such position, it follows to create the network of the special establishments - both state and non-state, - that will engage in preparation of such specialists for Ukraine, will prepare corresponding investment projects on international standards. Today here and there our businessmen, and especially farmers even cannot clearly set forth the requirements in investing, correctly to lay down a project or request on the receipt of foreign help.

\section{The basic problems of investments attraction in the agrarian sector at regional level}

In addition, for today there is a row of other negative moments: bureaucratic barriers, absence of the legal providing of crediting, insurance of risks, low level of business and professional qualification, lack of the attractive investment programs and projects, hard tax system.

The operating tax system must be corrected after such principal items: regulation of mutual relations between the state and taxpayers; stability of the tax system during a fiscal year, her simplicity and availability; responsibility is for ignoring of tax law; reduction of taxes amount and substantial of simplification procedure of their collection; common decline of tax load and defence of home producers; strengthening of stimulation of capital investments, reformation of depreciation politics; increase of property role and landed taxation, resource payments; reformation of the profits system distribution ; reduction of privileges.

The basic problems at regional level are:

- features of specialization of agriculture at regional level;

- absence of clear regional investment politics;

- absence of stimuli and mechanisms at local-authority for bringing in of investments;

- imperfection of the informatively-consultative providing at regional level.

Obviously, that a subzero investment attractiveness of agriculture is in the regions of Ukraine, unwillingness to inlay money in his development, except especially economic reasons, predefined by incuriosity or indifference of local-authority to the problem of investments attraction. The investment rating of regions of Ukraine testifies to the low professional level of local officials that is responsible for creation of investment climate, leads to subzero efficiency of local-authority efforts for the increase of territories investment attractiveness.

Further stratification of regions after the level of investment activity becomes a barrier on the way of single economic space forming in the agrarian sector of country's economy, strengthening of economic connections, 
becoming of regions as subjects of international investment activity. Weak investment positions of separate regions do not give an opportunity to extend an agricultural production, a social sphere does not develop accordingly. Regions become dependants in relation to the state and do not have economic stimuli to develop the agroindustrial complex.

Without regard to the accepted legislative acts, the system does not have a normatively-legal base that regulates the processes of investment activity. Her main defect is absence of legislative acts that clearly would prescribe the role of central and local executive and organs of local selfgovernment bodies in the process of investments attraction. Such plenary powers are washed out and determined in different legislative acts, that diminishes efficiency of their implementation.

Success of investment projects in a great deal depends on the government and local self-government bodies' openness to the dialogue with public and productive sphere (by an agribusiness).

Leading role in the process of attractiveness agrarian sector investment increasing in the regions of Ukraine it must belong to the state that owns for this purpose necessary money of budget and off-budget funds and able in the scales of entire country to define perspective directions and objects of investing. At the same time, organs of local self-government and local executive bodies must develop basic directions of investment politics on territory of region in relation to attract money of under perspective investment projects, to promote in determination of basic priorities of investing of region, coordinate investment projects, control the rational use of the got financial resources.

For activation of investment activity investment politics is needed with the clear mechanisms of realization on state and regional levels. Necessary general strategy of investment development of regions, that would determine priorities of investing on the basis of taking into account of them economic effect, but not today's and non-permanent, but perspective and stable.

To the basic problems at the level of separate agrarian enterprises is:

- risks, that the productions of agrarian goods related to the productive cycle;

- physically threadbare and morally the antiquated material and technical base of enterprises;
- subzero quality and insufficient competitiveness of agricultural produce;

- lack of operative market information.

Agriculture presents by a soba industrywith an unfavourable investment climate. The not high investment attractiveness of agrarian enterprises is explained by the specific of agriculture: by the high capacity of capital and comparatively low return of funds, by seasonality of production and considerable duration of productive cycle, by dependence on natural and climatic terms, high risks, slow money returning, low level of technological equipped and profitability.

Modern agrarian enterprises require considerable capital investments. The questions of search and attraction their economic complex of financially-material resources acquire the special actuality, as a result of updating necessity of operating production capacities and capital assets, decision of newest technologies introduction tasks, mastering of new competitive products types, increase of potential and creation of new workplaces.

Also is an obstacle on the way of both foreign and domestic investing in the economy of Ukraine shortage of commercial information about the market of Ukraine, her regions and concrete agrarian enterprises, transport and telecommunication systems, legal base. Especially it touches small and middle foreign companies and firms. Foreign investors are naturally interested in the new place of arms for the receipt of income due to the large internal market of Ukraine, her natural riches, skilled and cheap labour force, achievements of home SciTech.

\section{Conclusions}

Thus, basic obstacles in investments attraction in the agrarian sector of country economy are: the high risks, related to the specific of agriculture (climatic terms, duration of productive process), ecological aspect and economic situation in a country on the whole; subzero investment attractiveness of industry and agrarian enterprises, undeveloped infrastructure; high level of commercial banks lending rates; unwithstand politics of state interference and adjusting, that does not add to the confidence to the potential investors. The lineation of basic problems of investing agrarian to the sector grounds for the search of these problems decision that will assist the increase of the inlaid investments efficiency in development of agriculture.

\section{References}

Halushko, V.P. (2008). Metodolohichni ta praktychni aspekty rivnia derzhavnoi pidtrymky sil's'kohospodars'kykh tovarovyrobnykiv. Ekonomika APK. 3: p. 3-11.

Kasych, A.O. (2008). Vplyv biudzhetno-podatkovoi polityky na investytsijno-innovatsijnu aktyvnist' pidpryiemstv. Aktual'ni problemy ekonomiky. 11: p. 144-152.

Lanchenko, Ye.O. (2005). Formuvannia i realizatsiia investytsijnoi polityky v ahrarnomu sektori ekonomiky Ukrainy. Ahroinkom. 11-12: p. 59-64.

Martsyn, V. (2007). Udoskonalennia derzhavnoho rehuliuvannia investytsijnoi diial'nosti v ekonomitsi Ukrainy. Aktual'ni problemy ekonomiky. 5 (71): p. 52-53. 
Nepochatenko, O.O. (2008). Derzhavna pidtrymka pidpryiemstv APK cherez udoskonalennia systemy kredytuvannia. Ekonomika APK. 8: p. 95-100.

Plekhanov, D.O. (2010). Naukove zabezpechennia derzhavnoho upravlinnia ahropromyslovym vyrobnytstvom v Ukraini: dys. doktora ekon. nauk: 25.00.02. - K., 475 p.

\section{Ирина БЕЗПЬЯТА}

\section{ИНВЕСТИЦИОННАЯ ПОЛИТИКА УКРАИНЫ В АГРАРНОМ СЕКТОРЕ}

Аннотация. Целью данной статьи является изучение особенностей инвестиционной политики государства в аграрном секторе экономики, определение основных проблем привлечения инвестиций и предоставления предложений по формированию инвестиционной политики в аграрном секторе экономики Украины. Одной из актуальных проблем развития аграрного сектора экономики Украины в современных условиях является обеспечение сельского хозяйства необходимыми финансовыми и материальными ресурсами, основным источником которых являются инвестиции. В настоящее время Украина находится в инвестиционном кризисе, который характеризуется снижением инвестиционной деятельности субъектов хозяйствования из-за низкого уровня активности инвесторов. Причиной этого является неблагоприятный инвестиционный климат в стране, что в свою очередь возник из-за нестабильного положение страны и рискованного экономического положения. Сельское хозяйство является той продовольственной отраслью национальной экономики, состояние которой прямо пропорционально зависит от средств, вложенных в ее развитие, а именно - от интенсивности инвестиционной деятельности. Именно активная государственная инвестиционная деятельность в аграрном секторе является залогом его стабильного развития и результативности. Методика исследования заключается в том, что основной причиной кризиса сельскохозяйственного производства многие экономисты называют, прежде всего, ослаблением роли государственного регулирования и поддержки агропромышленного комплекса. В развитых странах, наоборот, усиливается значение государственной поддержки агропромышленного комплекса. Расходы на реализацию аграрной политики в виде прямой и косвенной поддержки постоянно растут, как это демонстрирует практика стран-ЕС. Нами определено общую схему рычагов государственного регулирования условий инвестирования в аграрном секторе экономики. Результаты исследования показывают, что важное условие, необходимое для частных капиталовложений (как иностранных, так и отечественных), - постоянный и общеизвестный набор норм и правил, сформулированных таким образом, чтобы потенциальные инвесторы могли понимать и предвидеть, что эти правила будут применяться к их деятельности. Практическое значение - определено успешностью инвестиционных проектов, которые во многом зависят от открытости органов власти и местного самоуправления, от диалога с общественностью и производственной сферой (агробизнесом). Значение/оригинальность. Результаты исследования позволяют определить основные препятствия в привлечении инвестиций в аграрный сектор экономики страны. Проявляются: высокие риски, связанные со спецификой сельского хозяйства (климатические условия, длительность производственного процесса), экологическим аспектом и экономической ситуацией в стране в целом; низкая инвестиционная привлекательность отрасли и аграрных предприятий, неразвитая инфраструктура; высокий уровень кредитных ставок коммерческих банков; неустоявшимся политика государственного вмешательства и регулирования, не добавляет уверенности потенциальным инвесторам. 